\title{
Silver Nanoparticle Production by Ruta graveolens and Testing Its Safety, Bioactivity, Immune Modulation, Anticancer, and Insecticidal Potentials
}

\author{
Hamed A. Ghramh $\left(\mathbb{D},{ }^{1,2,3}\right.$ Essam H. Ibrahim ${ }^{1 D},{ }^{1,3,4}$ Mona Kilnay, ${ }^{1,5}$ Zubair Ahmad, \\ Sadeq K. Alhag, ${ }^{2,3}$ Khalid Ali Khan, ${ }^{2,3}$ Ramadan Taha $\mathbb{C}^{3,7}$ and Fawziah M. Asiri ${ }^{8}$ \\ ${ }^{1}$ Research Center for Advanced Materials Science (RCAMS), King Khalid University, P.O. Box 9004, Abha 61413, Saudi Arabia \\ ${ }^{2}$ Unit of Bee Research and Honey Production, Faculty of Science, King Khalid University, P.O. Box 9004, \\ Abha 61413, Saudi Arabia \\ ${ }^{3}$ Biology Department, Faculty of Science, King Khalid University, P.O. Box 9004, Abha 61413, Saudi Arabia \\ ${ }^{4}$ Blood Products Quality Control and Research Department, National Organization for Research and Control of Biologicals, \\ Cairo, Egypt \\ ${ }^{5}$ Department of Microbiology, National Organization for Drug Control and Research (NODCAR), Cairo, Egypt \\ ${ }^{6}$ Biology Department, Faculty of Sciences and Arts, King Khalid University, Dhahran Al Janoub, Abha, Saudi Arabia \\ ${ }^{7}$ Department of Clinical Pathology, Faculty of Veterinary Medicine, Suez Canal University, Ismailia, Egypt \\ ${ }^{8}$ Department of Biology, Faculty of Science, University of Bisha, Bisha, 511, Saudi Arabia
}

Correspondence should be addressed to Essam H. Ibrahim; essamebrahim@hotmail.com

Received 13 February 2019; Revised 21 March 2019; Accepted 12 May 2019; Published 24 July 2020

Academic Editor: Jacopo Sgrignani

Copyright (c) 2020 Hamed A. Ghramh et al. This is an open access article distributed under the Creative Commons Attribution License, which permits unrestricted use, distribution, and reproduction in any medium, provided the original work is properly cited.

Ruta graveolens, a plant belonging to the family Rutaceae, is traditionally used as a medicinal plant and a flavoring agent in food. This work aimed to prepare silver nanoparticles (AgNPs) using the ethanol extract from R. graveolens leaves and test different biological activities as well as insecticidal potentials in the extract and extract prepared AgNPs. Dried and powdered R. graveolens leaves were subjected to extraction using ethanol, and this extract was used to synthesize AgNPs. AgNP synthesis was monitored by the change in color, UV spectrophotometry, and electron microscopy (scanning). Fourier transform infrared (FT-IR) spectroscopy was used to monitor the functional groups in the extracts. Immunological, physiological, anticancer, antibacterial, and insecticidal potentials of the extract and its prepared AgNPs were tested. Results showed the ability of the leaf extract to synthesize. SEM examination revealed a spherical shape of AgNPs with a size of 40-45 nm. The extract contained many functional groups as indicated by FT-IR. The extract alone inhibited the growth of normal rat splenic cells, while the extract containing AgNPs stimulated its growth. Extract alone stimulated HeLa cell proliferation and inhibited HepG2 growth, while both cell line growth was inhibited by the extract containing AgNPs. Both the extract and extract with AgNPs were safe on RBCs and did not cause any severe elevation in liver enzymes. The extract alone and with AgNPs showed insecticidal activity against Culex pipiens. Our findings suggest that the $R$. graveolens leaf extract, alone or with AgNPs, is biologically safe on animal cells and has antibacterial, insecticidal, and immunomodulation potentials.

\section{Introduction}

Herbal medicines that utilize plant extracts are increasingly used to treat a wide range of diseases, though very little knowledge about the mode of action of these plants is known $[1,2]$.
Ruta graveolens L. (Rutaceae), known in some countries as Sazab and has a common name as rue, is widely distributed in various geographical regions of Afro Asian countries [3]. This plant is cultivated as a decorative plant $[4,5]$ and is used in traditional medicine for treating many 
disorders such as hypertension, cramps to hysteria, edema, helminthes, skin conditions, gastrointestinal disorders, and womb diseases $[3,6,7]$. It is also used as a toxin antidote and insect repellent [8]; as a diuretic, antipyretic [5], anticancer [7], antifungal, antibacterial, purgative, antiparasitic, hepatoprotective, antioxidant, and hypotensive agent; and against epilepsy. Ancient Egyptians and early Greeks used rue to improve eyesight and was also used as an anti-inflammatory agent and immune stimulant and for the treatment of skin afflictions and malaria $[9,10]$. Ruta has been demonstrated to be advantageous for multiple sclerosis treatment [11] as well as hypotensive action [12].

Phytochemical investigations have demonstrated the presence of at least 120 chemical compounds found in all of the different parts of the plant. These include oils, fats, flavonoids, alkaloids, furoquinolines, glycosides, terpenoids, essential oils, steroids, coumarins, sterols, tannins, saponins, phenols, carbohydrates, pyranocoumarins, cardioglycosides, proteins, and amino acids. All parts of the plant contain the active compound, but they are mostly found in leaves $[13,14]$.

Nobel metal nanoparticles such as silver and gold have obtained increased interest because of their multipurpose applications in several fields such as biology, medicine, and industry [15]. The physiochemical properties of silver nanoparticles (AgNPs) made them get special attention [16]. Nanoparticles can be prepared by chemical and physical methods [17-19], but green synthesis using plants [20, 21], yeast, bacteria, and fungi [22] got more attention because it is nontoxic, clean, and ecofriendly. AgNPs have many biological properties such as anticancer, antimicrobial, antifungal, antiviral, anti-inflammatory [23-26], antiparasite [27], and insecticidal potentials [28]. In addition, silver nanoparticles have been used in the industries such as in paint, detergent [29], clothing [30], and pharmaceutical preparations [31]. Preparation of nanoparticles using a plant extract is valuable due to the ease of preparation methods with low biohazardous contents.

Silver nanoparticles produced by Ruta graveolens were shown to have many characteristics that include antibacterial, antifungal [32], dye degradation [33], antiviral [34], and sun protection factor [35].

This study was designed to prepare the Ruta graveolens leaf ethanol extract and prepare silver nanoparticles (AgNPs) using this extract. Both the extract and the extract containing AgNPs were tested for their biological safety and as an insecticide.

\section{Materials and Methods}

2.1. Preparation of Plant Extracts. Ruta graveolens leaves were gathered during the rainy season at Abha, Aseer, Kingdom of Saudi Arabia (KSA), in the month of February 2018. Identification of the plant was kindly done by a taxonomist at the Biology Department, King Abdul-Aziz University, Saudi Arabia. The collected leaves were rinsed with distilled water after extensive washing using tap water. After that, $R$. graveolens leaves were dried in shade at room temperature. Following the method described in [36], the active ingredients in the leaves were extracted. In brief, powder of the dried leaves was prepared by grinding, and $100 \mathrm{~g}$ of the obtained powder was mixed with $350 \mathrm{~mL}$ of $70 \%$ ethanol. The mixture was agitated for $40 \mathrm{~h}$ at room temperature and then filtered through a filter paper (Whatman No. 5). Using a rotary evaporator, the obtained flow-throw was dried at $40^{\circ} \mathrm{C}$ for $3 \mathrm{~h}$. The obtained dried material was about $4 \mathrm{~g}$ (semisolid crude extract). From this dried material, $1 \%$ acetone and $0.5 \%$ dimethyl sulfoxide (DMSO) stock solutions were prepared.

2.2. Synthesis of AgNPs Using R. graveolens Extract. To an Erlenmeyer flask, $98.5 \mathrm{~mL} 1 \mathrm{mM} \mathrm{AgNO} 3,0.5 \mathrm{~mL}$ Triton X-100 (both are from Sigma-Aldrich), and $1 \mathrm{~mL}$ acetone plant extract solution were added to prepare silver nanoparticles (AgNPs) [36]. The flask was incubated at room temperature until the color of the mixture changed (about $24 \mathrm{~h})$.

2.3. Characterization of $R$. graveolens-Produced AgNPs. Using a UV-3600 Shimadzu spectrophotometer, the production of AgNPs was monitored at the wavelengths from 200 to $600 \mathrm{~nm}$ at $1 \mathrm{~nm}$ resolution [36]. The shape and size of the produced AgNPs were characterized using a scanning electron microscope (SEM, JEM-1011, JEOL, Tokyo, Japan) at an accelerating voltage of $90 \mathrm{kV}$. Fourier transform infrared (FT-IR) spectroscopy (PerkinElmer Spectrum 2000, USA) within the range $600-4000 \mathrm{~cm}^{-1}$ at a rate of 16 times, and a clarity of $4 \mathrm{~cm}^{-1}$ was used to explore the functional groups in the plant extract alone or with AgNPs.

\subsection{Antibacterial Activities}

2.4.1. Antibacterial Activity Assay. Bacterial strains: Gramnegative (Escherichia coli, Proteus mirabilis, and Shigella flexneri) and Gram-positive (Staphylococcus aureus) bacteria were used. These bacteria were kindly supplied by the Microbiology Lab, Biology Department, Faculty of Sciences and Arts, King Khalid University, Dhahran Al Janoub, Saudi Arabia, and were maintained at $4^{\circ} \mathrm{C}$ on nutrient agar slants. Nutrient agar and nutrient broth (Sigma-Aldrich) were prepared according to the manufacturer's instructions.

2.4.2. Well Diffusion Assay for Antibacterial Activity. The antibacterial potential of the Ruta graveolens leaf extract and the extract prepared AgNPs was tested using the agar well diffusion method. Bacterial strains (Gram-negative Escherichia coli, Proteus mirabilis, and Shigella flexneri and Grampositive Staphylococcus aureus) were inoculated into $15 \mathrm{~mL}$ nutrient broth and shaken $(225 \mathrm{rpm})$ overnight at $37^{\circ} \mathrm{C}$. Nutrient agar plates were prepared, and $6 \mathrm{~mm}$ wells in each plate were punched out. Separate plates were covered with one of the overnight bacterial suspension $(50 \mu \mathrm{L})$ by spreading using a sterile cotton swap. Plant extract in DMSO and its prepared silver nanoparticles $(30 \mu \mathrm{L}$ each) were aseptically pipetted into the wells of agar plates separately. The positive control (penicillin/streptomycin at 20 units/ 
$20 \mu \mathrm{g}$, respectively) solution and the negative control (nutrient broth) solution, $30 \mu \mathrm{L}$ each, were included. Different plates were incubated for $24 \mathrm{~h}$ at $37^{\circ} \mathrm{C}$, and zones $(\mathrm{mm}$ diameter) of inhibition around each well were measured in triplicate [37].

\subsection{In Vitro Effects of Ruta graveolens Leaf Extract and Extract Prepared AgNPs on Normal Splenic Cell Proliferation}

2.5.1. Splenic Cell Culture Preparation. The test was done according to the procedures described in [38] with little modifications. Splenic single-cell suspension was prepared from healthy adult male Sprague Dawley rats weighing about $280 \mathrm{~g}$. The rat was kindly supplied by the animal house found at King Khalid University. The cells were suspended at a density of $0.05 \times 10^{6} / \mathrm{mL}$ in a complete RPMI-1640 medium consisting of $10 \%$ fetal calf serum (Gibco), penicillin/ streptomycin $100 \mathrm{U} / 100 \mu \mathrm{g} / \mathrm{ml}$ (Gibco), $2 \mathrm{mM}$ L-glutamine (Gibco), $2 \mathrm{mM}$ sodium pyruvate (Seromed), 2\% sodium bicarbonate (Seromed), pH 7.2, and HEPES ( $N$-2-hydroxyethylpiperazine- $N$-2-ehtanesulfonic acid) buffer (Sigma). The cell culture was performed on a 96-microwell tissue culture plate (Coaster) by adding $100 \mu \mathrm{L}$ of cell suspension (5000 cells/well) and $100 \mu \mathrm{L}$ Ruta graveolens leaf extract or extract prepared AgNPs at 200, 100, and $50 \mu \mathrm{g} / \mathrm{mL}$ separately.

2.5.2. Study of Cytotoxic/Proliferative Effects. Potentiality of the $R$. graveolens leaf extract and extract prepared AgNPs to kill splenic cells (cytotoxicity) or to induce normal cell division was tested by adding different concentrations of the $R$. graveolens leaf extract and extract prepared AgNPs at final concentrations of 200,100 , and $50 \mu \mathrm{g} / \mathrm{mL}$ to wells containing 5000 cells/well rat splenic cells prepared as mentioned above separately in triplicate. The control culture was prepared by adding 5000 splenic cells/well in $200 \mu \mathrm{L}$ of the culture medium. All plates were incubated in a $\mathrm{CO}_{2}$ incubator (Memmert, $\mathrm{GmbH}$ ) at $37^{\circ} \mathrm{C}$ for $72 \mathrm{~h}$. The viability of the cells in all plates was assessed using the $\mathrm{Vybrant}^{\circledR}$ MTT cell proliferation assay kit (Thermo Fisher Scientific) according to the manufacturer's instructions.

The percentage increase or decrease in cell number was calculated according to the formula given in [39].

\subsection{Lytic Effects of Ruta graveolens Leaf Extract and Extract} Prepared AgNPs on Red Blood Cells (RBCs). The hemolytic activity which may be found in the $R$. graveolens leaf acetone extract and its biosynthesized AgNPs was tested separately at a final concentration of $200 \mu \mathrm{g} / \mathrm{mL}$ according to the method described in [39] using 10\% hematocrit fresh cow red blood cells (RBCs) suspended in the phosphate-buffered saline (PBS, pH 7.4). To $900 \mu \mathrm{L}$ of prepared RBCs, $100 \mu \mathrm{L}$ of the acetone $R$. graveolens leaf extract and $R$. graveolens leaf extract prepared AgNPs were added in $1.5 \mathrm{~mL}$ tubes separately and incubated for $60 \mathrm{~min}$ at $37^{\circ} \mathrm{C}$. The positive control was prepared by adding $100 \mu \mathrm{L}$ of $1.5 \%$ Triton $\mathrm{X}-100$ to $900 \mu \mathrm{L}$ of prepared RBCs (positive control), and the negative control was prepared by adding $100 \mu \mathrm{L}$ PBS to $900 \mu \mathrm{L}$ of prepared RBCs. At the end of the incubation, all tubes were centrifuged for $10 \mathrm{~min}$ at 2,000 rpm; supernatants were taken from the tubes, and the absorbance of each test was measured at $576 \mathrm{~nm}$. The percentage of hemolysis was determined using the following equation:

$$
\% \text { hemolysis }=\left[\frac{\text { absorbance of sample }- \text { absorbance of negative control }}{\text { absorbance of positive control }- \text { absorbance of negative control }}\right] \times 100 \text {. }
$$

2.7. Acute Cytotoxicity Study of Ruta graveolens Leaf Extract and Extract Prepared AgNPs. To test the hepatic toxicity which may be found in the $R$. graveolens leaf extract or extract prepared AgNPs, 5 adult healthy rats (200-250 g) were injected with a single dose regimen of $100 \mu \mathrm{g} / \mathrm{mL}$ of the $R$. graveolens leaf extract or extract prepared AgNPs [39]. The rats were left for $24 \mathrm{~h}$ and then sacrificed, and sera were obtained from their blood. Liver function was tested by assaying the level of serum aspartate aminotransferase (AST) colorimetrically according to the Reitman and Frankel method using the Randox kit (UK).

2.8. Mosquito Larvicidal Activity. The larval susceptibility test was conducted according the method given by the WHO [40]. Early $4^{\text {th }}$ instar larvae of Culex pipiens were treated with various concentrations of $R$. graveolens (1000-5000 ppm) and its prepared AgNPs (50-250 ppm) for $24 \mathrm{~h}$ in groups of glass beakers containing $100 \mathrm{~mL}$ of tap water. Five replicates of 20 larvae each per concentration, and so in the control, were set up and kept in an environmental chamber at $27^{\circ} \mathrm{C}$ with a photoperiod of $16: 8 \mathrm{~h}$ light/dark regimen. The larvae were given the usual larval food during these experiments. Larval mortalities were recorded at $24 \mathrm{~h}$ after treatment. The dead larvae were identified when they failed to move after being probed by a needle in the siphon or cervical region.

2.9. Anticancer Activity Test. The cell lines HepG2 and HeLa were used to test the anticancer potential of the $R$. graveolens leaf extract. The cells were maintained and grown in the supplemented minimal essential medium (MEM), containing fetal calf serum (10\%), penicillin/streptomycin $(100$ $\mathrm{U} / \mathrm{mL} / 100 \mu \mathrm{g} / \mathrm{mL})$, and L-glutamine $(2 \mathrm{mM})$ at $37^{\circ} \mathrm{C}$ and $5 \%$ $\mathrm{CO}_{2}\left(\mathrm{CO}_{2}\right.$ incubator). After reaching confluency, the cells were trypsinized ( $2 \%$ trypsin-EDTA) to prepare single-cell suspension. Single-cell suspension was adjusted to $1 \times 10^{5} /$ $\mathrm{mL}$, and then $100 \mu \mathrm{L}\left(10^{4}\right.$ cells $)$ were plated into each well of the 96-well plate and incubated overnight in a $\mathrm{CO}_{2}$ 
incubator. The medium in the plate was decanted, and $200 \mu \mathrm{L}$ media containing the $R$. graveolens leaf extract at the concentration of $200 \mu \mathrm{g} /$ well was added. The plate was incubated for an additional 24 hours in a $\mathrm{CO}_{2}$ incubator. The media in wells were replaced with a fresh $100 \mu \mathrm{L} /$ well culture medium. The viability of the cells was monitored using the Vybrant ${ }^{\circledR}$ MTT cell proliferation assay kit (Thermo Fisher Scientific) according to the manufacturer's instructions [41].

\section{Statistical Analysis}

The study was conducted in a completely randomized design (CRD) in a factorial experiment. All data were statistically analyzed using the analysis of variance (ANOVA), and means were compared by LSD at $P \leq 0.05$ using the SAS software program, SAS Institute (2006) version 9.3. $\mathrm{LC}_{50}$, $\mathrm{IC}_{50}$, and $\mathrm{IC}_{95}$ were calculated according to the probit analysis program [42]. Computerized log-probit analysis was used to analyze values, regression equations, 95\% confidence intervals, and degrees of freedom of the $\chi^{2}$ goodness of fit tests. Using Abbot's formula [43], the mortality percent was corrected for control mortality.

\section{Results and Discussion}

4.1. Characterization of AgNPs. The plant extract was mixed with silver nitrate to synthesize AgNPs. The change in the color of the mixture was an indication of AgNP synthesis where the color of the solution changed from yellow to brown and continued to dark brown (Figures 1(a) and 1(b)). The degree of color change was time dependent that enabled the visual monitoring by observation. This change in color may be assigned to the excitation of the surface plasmon response of AgNPs [44]. Color changes of the solutions are due to some chemical compounds such as alkaloids, flavonoids, saponins, and steroids, and the plant extract may act as a reducing agent that reduced silver ions $\left(\mathrm{Ag}^{+}\right)$to a silver atom $\left(\mathrm{Ag}^{0}\right)$ by active biomolecules that are found in the plant extract through an enzyme like nitrate reductase. Many enzymes released into the solution have the capability to reduce the silver ions in the form of nanoparticles through agents working as capping molecules such as proteins [44].

The nanoparticle synthesis was accomplished via onepot reaction, including the reduction of silver ions using the ethanol extract of $R$. graveolens. Using the UV-Vis absorption, the spectrum of the solution indicated that the surface plasmon resonance that is derived from the silver nanoparticles was around $412-488 \mathrm{~nm}$, which is the specific area of silver nanoparticles (Figures 1(c) and 1(d)). SEM analysis revealed that the prepared AgNPs are almost uniform spherical in shape with a size of 40-45 nm (Figure 2).

The function of the leaf extract to act as a reducing and capping agent may be due to the domination of several functional groups which were confirmed by FT-IR analysis of the extract containing AgNPs. FT-IR spectroscopy analyses were carried out to recognize the biological entities responsible for capping and stabilizing of AgNPs synthesized using $R$. graveolens. The FT-IR spectra of AgNPs prepared by the leaf extract of $R$. graveolens (Figure 3) showed a vibrational band at $3750 \mathrm{~cm}^{-1}$ that was assigned to $\mathrm{O}-\mathrm{H}$ arising due to alcohols and phenols. The band at $3300 \mathrm{~cm}^{-1}$ corresponds to $\mathrm{N}-\mathrm{H}$, indicating the presence of primary and secondary amines. The strong stretching vibrational band at $2120 \mathrm{~cm}^{-1}$ may be assigned to $\mathrm{N}=\mathrm{N}=\mathrm{N}$ and $\mathrm{N}=\mathrm{C}=\mathrm{N}$ related to azide and carbamide. $\mathrm{A}$ weak band at $2000 \mathrm{~cm}^{-1}$ may be due to $\mathrm{C}=\mathrm{C}=\mathrm{C}$ and $\mathrm{C}=\mathrm{C}=\mathrm{N}$, corresponding to allene and ketenimine. The sharp peak at $1630 \mathrm{~cm}^{-1}$ may be assigned to $\mathrm{C}=\mathrm{C}$, corresponding to alkene. A weak bending band at $1380 \mathrm{~cm}^{-1}$ may be assigned to $\mathrm{C}-\mathrm{H}$, corresponding to aldehyde and alkane. A weak stretching band at $1250 \mathrm{~cm}^{-1}$ indicates $\mathrm{C}-\mathrm{O}$ and $\mathrm{C}-\mathrm{N}$, corresponding to aromatic ester and amine. A stretching vibrational band at $500 \mathrm{~cm}^{-1}$ assigned to C-I corresponds to the halo compound [45].

Some works showed that the ethanol extract of the $R$. graveolens plant contained more than 120 compounds such as flavonoids and furoquinolines, coumarins, acridone alkaloids, and essential oils [46]. The components of the $R$. graveolens species are of medical importance because they have a broad range of biological activities which led to some of them being used in medication. Alcoholic extracts of $R$. graveolens have been examined for their antiproliferative effect, using many types of cancer cell lines to test their potentiality as a therapeutic in oncology [47-49].

4.2. Antibacterial Activity. The results of testing the antibacterial activity of the $R$. graveolens leaf extract and extract prepared AgNPs against Gram-positive and -negative bacteria are shown in Table 1. Both the plant leaf extract and the extract prepared AgNPs inhibited the bacterial pathogens. Average diameters of inhibition zones produced by plant extract + AgNPs against both Gram-negative and -positive bacteria were bigger than those produced by the plant extract alone.

Previously, many types and sizes of nanoparticles were effectively used to induce the delivery of therapeutic agents $[50,51]$ to cure bacterial infections in the skin [52]. Also, nanoparticles were used to prevent colonization of bacteria on the surface of medical devices and as an antibacterial agent in food and clothing industries [53]. Because of their unique and nearly known mode of action and antimicrobial properties against Gram-positive and -negative bacteria and the need for developing a new generation of antibiotics, nanoparticles are on the spot as an alternative to traditional antibiotics to bypass the problem of drug resistance.

4.3. Cytotoxic/Proliferative Effects. The cytotoxic or stimulatory properties that may be found in $R$. graveolens were studied at different concentrations. The results showed that there were growth inhibitor/cytotoxic effects of the $R$. graveolens leaf extract on normal rat splenic cells, while the extract containing AgNPs showed stimulatory effects on normal splenic cells (Figure 4 and Table 2).

Many constituents of Ruta graveolens extracts such as alkaloids, quinolone alkaloids, graveolens, flavonoids, undecyl acetates, and mananones may contribute to its cytotoxic activity. The cytotoxic effects of Ruta extracts may 

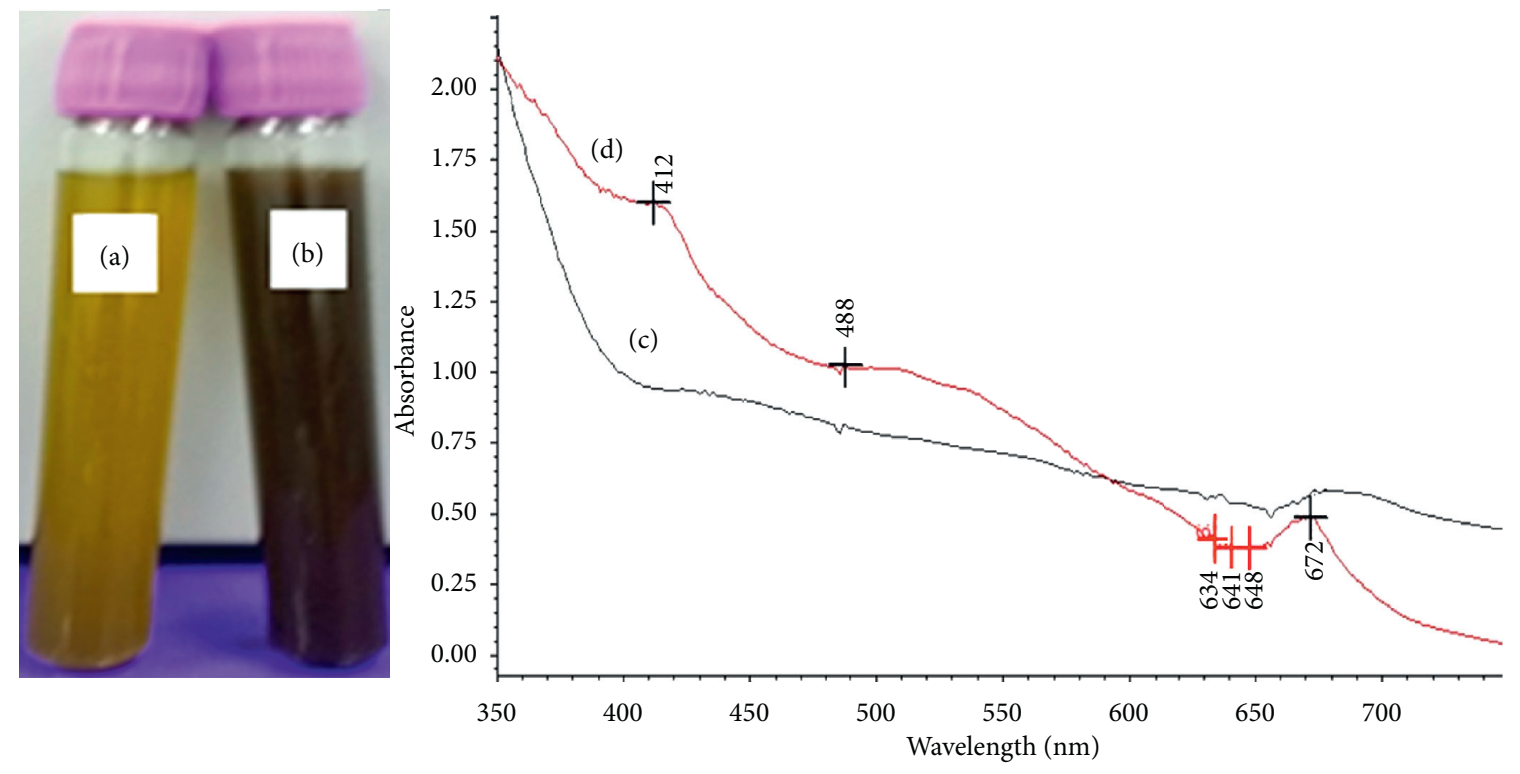

FIgURE 1: Silver nanoparticle (AgNP) synthesis by the $R$. graveolens leaf extract: (a) extract alone; (b) extract after adding silver nitrate; (c) light absorbance of the extract alone; (d) light absorbance of the extract with AgNPs.

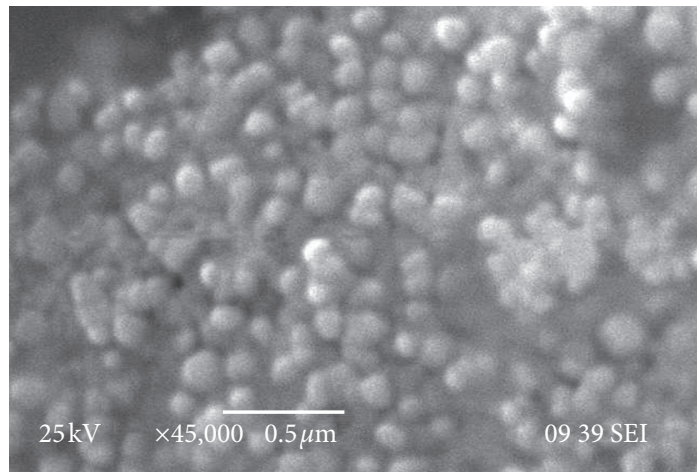

FIGURE 2: The SEM image showing the spherical silver nanoparticles.

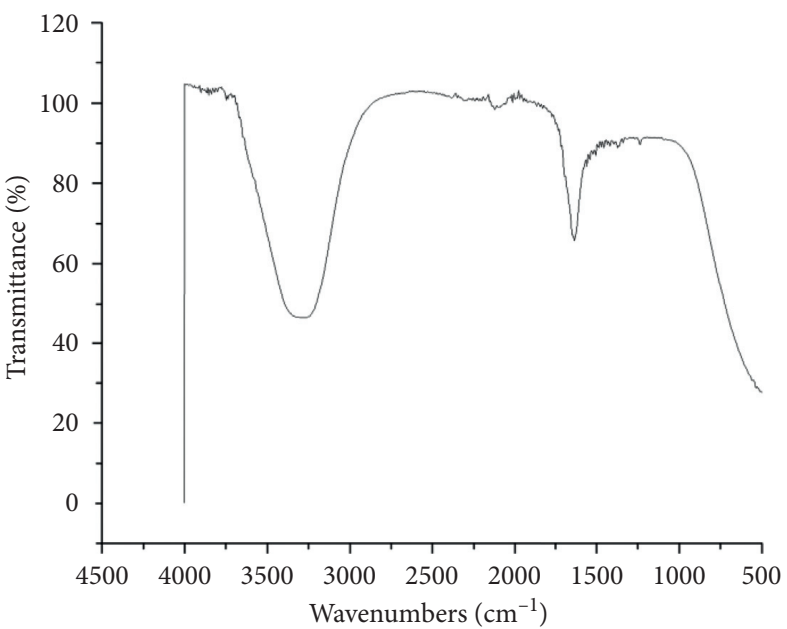

(a)

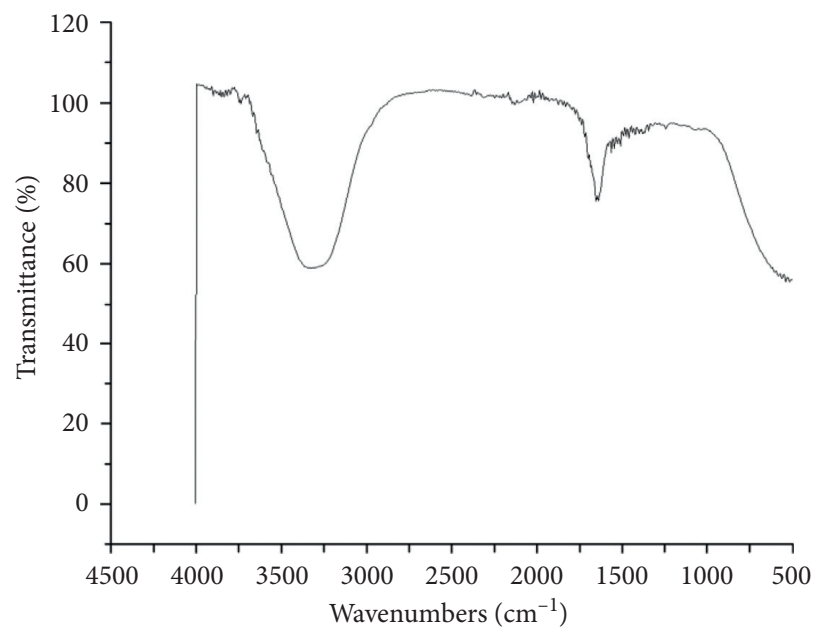

(b)

Figure 3: FT-IR spectra of the leaf extract of $R$. graveolens (a) before the addition of $\mathrm{AgNO}_{3}$ and (b) after addition of $\mathrm{AgNO}_{3}$. 
TABLE 1: Antibacterial potentials of the Ruta graveolens leaf extract and extract containing AgNPs.

\begin{tabular}{lcccc}
\hline & & \multicolumn{2}{c}{ Inhibition zone $(\mathrm{mm})$} \\
Treatments & E. coli & P. mirabilis & S. aureus & \\
& $6.33 \pm 0.58^{\mathrm{c}}$ & $6.67 \pm 1.15^{\mathrm{c}}$ & $6.33 \pm 0.58^{\mathrm{c}}$ & \\
Extract & $16.33 \pm 1.52^{\mathrm{b}}$ & $15.00 \pm 1.00^{\mathrm{b}}$ & $13.00 \pm 1.00^{\mathrm{b}}$ & $7.33 \pm 1.15^{\mathrm{c}}$ \\
Extract + AgNPs & $21.67 \pm 1.15^{\mathrm{a}}$ & $20.33 \pm 0.58^{\mathrm{a}}$ & $22.67 \pm 1.15^{\mathrm{a}}$ & $12.67 \pm 0.58^{\mathrm{b}}$ \\
Control (positive) & $0.00 \pm 0.00^{\mathrm{d}}$ & $0.00 \pm 0.00^{\mathrm{d}}$ & $0.00 \pm 0.00^{\mathrm{d}}$ & $20.00 \pm 1.00^{\mathrm{a}}$ \\
Control (negative) & & & $0.00 \pm 0.00^{\mathrm{d}}$ \\
\hline
\end{tabular}

Inhibition zones are presented as an average of triplicate \pm SD. Means with the same superscript letters indicate nonsignificant differences.

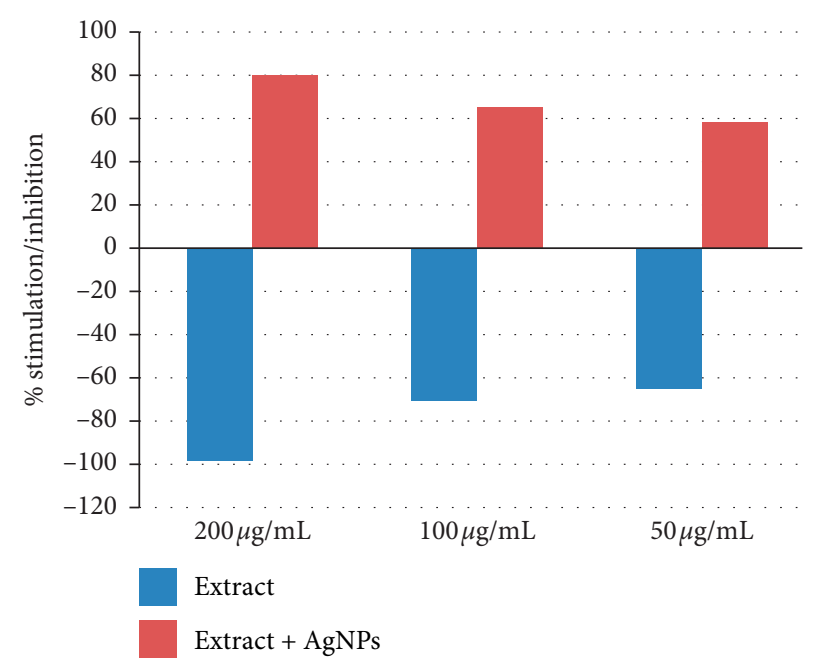

Figure 4: Percent growth stimulation index of normal rat splenic cells after treatment with the leaf extract of $R$. graveolens alone (growth inhibition) and the extract with AgNPs (growth stimulation).

TABLE 2: Effects of the R. graveolens leaf extract and extract with AgNP treatment on normal rat splenic cell growth stimulation/inhibition.

\begin{tabular}{lcc}
\hline$(\mu \mathrm{g} / \mathrm{mL})$ & $\begin{array}{c}\text { \% of splenic cell growth inhibition/stimulation } \\
\text { R. graveolens leaf extract with AgNPs }\end{array}$ \\
\hline 200 & $-98.13 \pm 3.50$ & $79.68 \pm 3.5$ \\
100 & $-70.22 \pm 1.80$ & $65.19 \pm 1.80$ \\
50 & $-64.87 \pm 1.44$ & $57.50 \pm 1.30$ \\
\hline
\end{tabular}

$\%$ of splenic cell inhibition is expressed as the average of triplicate \pm SD.

be attributed to the induction of DNA damage, causing chromosomal aberrations. They are also reported to be phototoxic, mutagenic, and capable of binding to DNA to induce apoptosis [7]. Flavonoids are reported to be genotoxic and possess oxidant activities. This pro-oxidant activity has been attributed to the apoptotic-inducing property of these flavonoids, and hence implicated in cancer chemoprevention [54]. The study [7] on Ruta graveolens found that it produced ROS (reactive oxygen species) and also induced apoptosis, and hence the cytotoxicity activity. Alkaloids were obtained from leaves and stem extracts of rue. Alkaloids are common constituents of other Rutaceae plants [54]. Alkaloids are known to have cytotoxic effects [55]. This explains why the cytotoxic effects decreased with the decrease in the plant concentration added to the normal rat splenic cells. Terpenoids are the largest class of naturally occurring compounds having mainly cytotoxic properties. A large number of terpenoids exhibit cytotoxicity against a variety of cells $[56,57]$.

The inhibitory effects of the extract decreased with the decrease in the extract concentration. Also, the stimulatory effects decreased with the decrease in the nanoparticle containing extract.

The cytotoxic effects of $R$. graveolens have been demonstrated by other studies [58]. In addition, $R$. graveolens was found to have antitumor activity [7], indicating its toxic behaviors. The stimulatory effects of the extract in the presence of AgNPs may be due to the antagonistic effects of the nanoparticles with the active toxic compounds found in the extract.

4.4. Lytic Effects of Ruta graveolens Leaf Extract and Extract with AgNP Treatment on RBCs. The degree of RBC lysis was calculated by comparing the absorbance of the target sample 
to the positive and negative controls (Table 3 ). The positive control demonstrated $100 \%$ RBC lysis, while the negative control demonstrated $0 \% \mathrm{RBC}$ lysis. The acetone plant extract containing AgNPs showed 100\% RBC lysis while that without AgNPs showed 9.58\% RBC lysis (Figure 5 and Table 3). The lysis effect of the extract containing AgNPs may be due to the direct effect of the nanoparticles on the membranes of the RBCs. Other studies referred the hemolytic effects as due to the induced release of oxidative stress products following exposure [59].

4.5. Acute Cytotoxicity Study of R. graveolens Leaf Acetone Extract and Its Biosynthesized AgNPs. The hepatic toxicity which may be found in prepared extracts was tested in adult healthy rats. The levels of serum aspartate aminotransferase (AST) showed a nonsignificant increase (1.16 fold increase) in the extract alone and the same (1.09 fold increase) in the extract with AgNPs. These results indicate the plant is safe and can be used without any systemic toxic effects. Many authors demonstrated the cytotoxic effects of AgNPs on the liver either in vivo [60] or in vitro [61]. In our study, the extract containing AgNPs showed no toxic effects on the liver in vivo. This may be due to the bioactive compounds found in the extract that abrogated the toxic effects of the nanoparticles on the liver.

4.6. Larvicidal Effects of R. graveolens Extract and Its Silver Nanoparticles on Cx. pipiens. Susceptibility levels of $C x$. pipiens larvae following treatments with different concentrations of $R$. graveolens and $R$. graveolens synthesized AgNPs against $4^{\text {th }}$ larval instars of $C x$. pipiens are described in Table 4.

In general, 31.633-92.857\% and 48.98-99.898\% larval mortalities were obtained when the $4^{\text {th }}$ instar larvae of $C x$. pipiens were treated with the effective concentrations of $R$. graveolens alone (1000-5000 ppm) and R. graveolens with silver nanoparticles (50-250 ppm), respectively. The results showed a significant positive correlation between the tested concentrations and the percentage of larval death for both the extract alone and the extract containing nanoparticles. Taking the concentration which kills 50\% of larvae $\left(\mathrm{LC}_{50}\right)$ and $\mathrm{LC}_{90}$ values into consideration, the records showed that the $R$. graveolens with silver nanoparticles caused $\mathrm{LC}_{50}$ at $56.002 \mathrm{ppm}$ and $\mathrm{LC}_{90}$ at $151.377 \mathrm{ppm}$, proving that the extract with nanoparticles is more effective than the extract of $R$. graveolens alone that showed $\mathrm{LC}_{50}$ at $1673.804 \mathrm{ppm}$ and $\mathrm{LC}_{90}$ at $5460.374 \mathrm{ppm}$, meaning that the extract with nanoparticles has a potency exceeding the extract alone by about 29.888 folds (Figure 6 and Table 5).

The results obtained from this study showed that the effect of the extract of $R$. graveolens and the nanoparticles against the larvae of the $C x$. pipiens are in accordance with those reported by other works $[62,63]$.

Kumar et al. [64] reported that $43 \%$ mortality was noted for fourth instar larvae of Culex quinquefasciatus treated with $S$. xanthocarpum, $\mathrm{LC}_{50}=155.29,198.32$, 271.12, 377.44, and $448.41 \mathrm{ppm} ; \mathrm{LC}_{90}=687.14,913.10,1011.89,1058.85$, and
TABLE 3: Absorbance of lysed RBCs as a result of the R. graveolens leaf acetone extract and extract prepared AgNP treatment.

\begin{tabular}{lcc}
\hline Treatment & $\begin{array}{c}\text { Absorbance at } \\
\text { wavelength of } \\
576 \mathrm{~nm}\end{array}$ & $\begin{array}{c}\text { RBC } \\
\text { hemolysis } \\
(\%)\end{array}$ \\
\hline Plant leaf acetone extract & 0.348 & 9.58 \\
Plant biosynthesized silver & $>3.00$ & 100 \\
nanoparticles (AgNPs) & 0.067 & 0 \\
Control (negative) & $>3.00$ & 100 \\
Control (positive) &
\end{tabular}

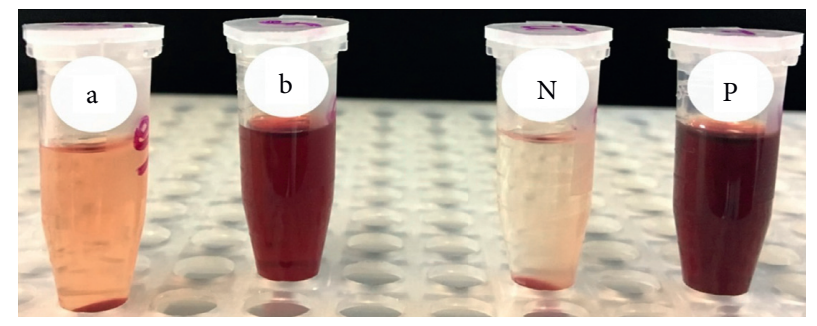

FIgURE 5: The effect of (a) $R$. graveolens leaf acetone extract alone and (b) its biosynthesized AgNPs on cow RBCs, where $\mathrm{N}$ is the negative control and $\mathrm{P}$ is the positive control.

TABle 4: Susceptibility level of Culex pipiens larvae to the $R$. graveolens extract and extract containing AgNPs, following continuous exposure for $48 \mathrm{~h}$.

\begin{tabular}{lcc}
\hline \multirow{2}{*}{$\begin{array}{l}\text { Concentration } \\
(\mathrm{ppm})\end{array}$} & $\begin{array}{c}\text { Observed response \% } \\
\text { extract }\end{array}$ & $\begin{array}{c}\text { graveolens graveolens extract with } \\
\mathrm{AgNo}_{3}\end{array}$ \\
\hline 1000 & $31.633 \pm 0.82$ & $48.980 \pm 1.18$ \\
2000 & $54.082 \pm 0.92$ & $69.388 \pm 1.77$ \\
3000 & $72.449 \pm 1.11$ & $89.796 \pm 2.93$ \\
4000 & $79.592 \pm 1.23$ & $96.939 \pm 2.88$ \\
5000 & $92.857 \pm 2.50$ & $99.898 \pm 3.51$ \\
\hline
\end{tabular}

1141.65 ppm, respectively. The bioactivity of the plant as well as AgNPs against the larval instars of Ae. aegypti and An. stephensi mosquito larvae was determined, and the results of AgNPs showed excellent larvicidal activity of the first, second, third, and fourth instar larvae, which exhibit noticeable effects after 24 or $48 \mathrm{~h}$ of exposure at their LC $_{50}$ and $\mathrm{LC}_{90}$ values [65].

4.7. Effects on Cancer Cells. Effects of the R. graveolens extract and extract-generated AgNPs on HeLa and HepG2 cancer cell lines were studied at one concentration. Results showed the ability of the extract alone to diminish the cell growth of the HepG2 cell line but not of the HeLa line. The extract containing AgNPs could lower the growth rate of both cell lines (Figure 7). Similar results were obtained by other studies [66] as they showed that the extract of $R$. graveolens has anticancer effects on some cancer cell lines but not on the HeLa cell line.

Alcoholic extracts of $R$. graveolens have been tested for its antiproliferative power against many types of cancer cells [47-49] and was found to inhibit the growth of these cell lines 


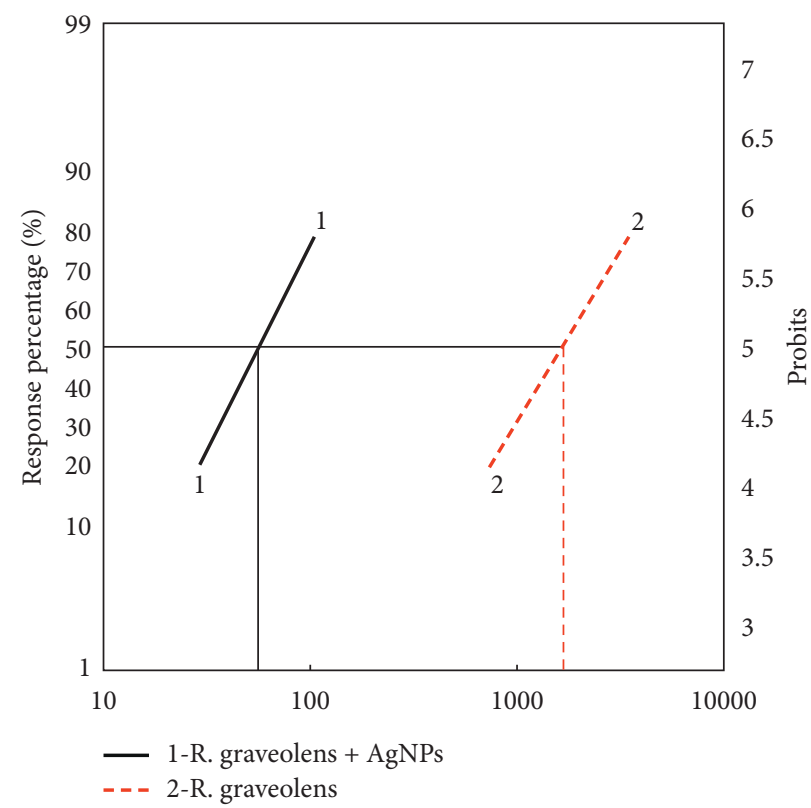

Figure 6: The relationship between concentrations of selected plant extracts and mortality percentage of $4^{\text {th }}$ instar larvae of $C x$. pipiens. Line 1: R. graveolens $+\mathrm{AgNo}_{3}$; Line 2: R. graveolens.

Table 5: The toxic effect of the R. graveolens extract and its AgNPs on the $4^{\text {th }}$ instar larvae of Cx. pipiens.

\begin{tabular}{|c|c|c|c|c|c|c|c|}
\hline No. & Line name & $\mathrm{LC}_{50}(\mathrm{ppm})$ & Lower limit & Upper limit & $\mathrm{RR}^{\mathrm{a}}$ & Slope & $\mathrm{LC}_{90}(\mathrm{ppm})$ \\
\hline 1 & R. graveolens $+\mathrm{Ag}$ & 56.002 & 46.515 & 64.424 & & 2.968 & 151.377 \\
\hline 2 & R. graveolens & 1673.804 & 1434.603 & 1892.906 & 29.888 & 2.496 & 5460.374 \\
\hline
\end{tabular}

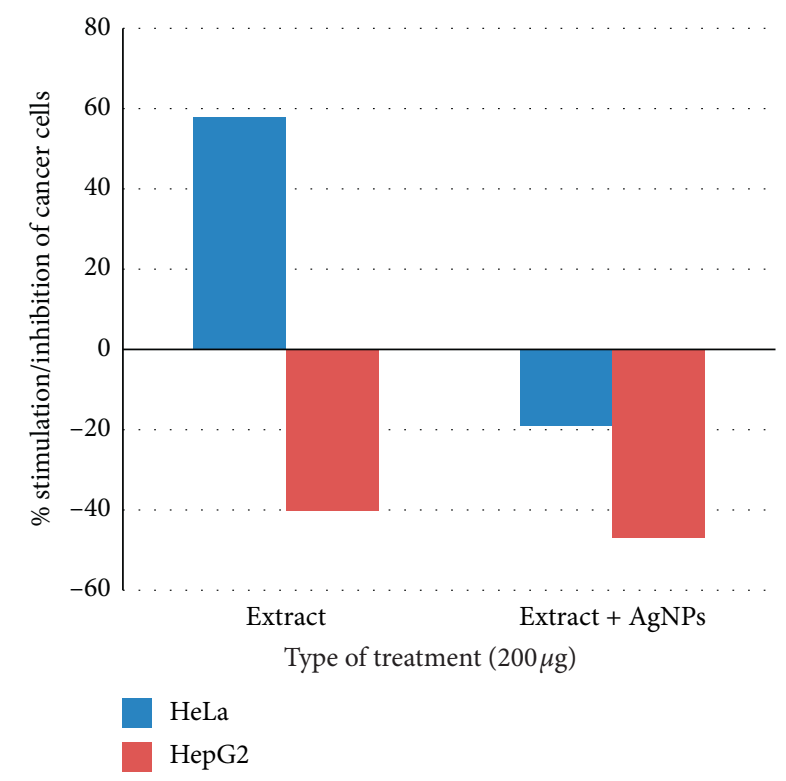

FIGURE 7: Effects of leaf extracts of $R$. graveolens alone or with AgNPs treatment on HeLa and HepG2 cell line growth stimulation/ inhibition.

by many mechanisms. In our study, the $R$. graveolens leaf extract, alone or with AgNPs, inhibited the growth of HepG2.

Generally, the mixing of a plant extract with silver nitrate has led to potentiation. This may be due to the synergy that occurs between the extract and the silver particles during the reduction process, as the compounds present in the extract are connected to the surface of the particles, increasing the strength of their effectiveness [67]; or the strength of the effect may in turn be due to their small size, which make them easy to pass through the wall of the body into the cells where they interfere with the process of dissociation and other physiological processes, and this is consistent with that stated in [68].

\section{Conclusion}

From the above results, we can conclude that the leaf extract of R. graveolens could synthesize AgNPs with a size of 40-45 nm. The extract contained functional groups that inhibited the growth of splenic and HepG2 cells and stimulated HeLa cell proliferation. The extract and extract containing AgNPs are safe on RBCs and vital organs. The extract alone and with AgNPs showed insecticidal activity against Culex pipiens.

\section{Data Availability}

The data used to support the findings of this study are included within the article.

\section{Conflicts of Interest}

All authors state that they do not have any financial/commercial conflicts of interest regarding this work. 


\section{Acknowledgments}

The authors extend their appreciation to the Deanship of Scientific Research at King Khalid University for funding this work through the Research Project (RCAMS/KKU/ 003/20).

\section{References}

[1] J. Patil Sharangouda and B. Patil Saraswati, “Toxicity studies on hepatic, nephric and endocrine organs of Citrus medica seeds extract on of female albino mice," Journal of Global Pharma Technology, vol. 3, no. 1, pp. 14-21, 2011.

[2] K. Shah, D. Sheth, P. Tirgar, T. Desai, M. Kher, and D. Rangani, "Anti-inflammatory activity of triticum aestivum on carrageenan induced paw edema in wistar rats," Pharmacologyonline, vol. 2, pp. 745-751, 2010.

[3] S. E. I. El Agraa, S. M. A. El Badwi, and S. E. I. Adam, "Preliminary observations on experimental Ruta graveolens toxicosis in Nubian goats," Tropical Animal Health and Production, vol. 34, no. 4, pp. 271-281, 2002.

[4] S. A. Arias-Santiago, M. A. Fernández-Pugnaire, F. M. Almazán-Fernández, C. Serrano-Falcón, and S. SerranoOrtega, "Phytophotodermatitis due to Ruta graveolens prescribed for fibromyalgia," Rheumatology, vol. 48, no. 11, p. 1401, 2009.

[5] T.-S. Wu, L.-S. Shi, J.-J. Wang et al., "Cytotoxic and antiplatelet aggregation principles of Ruta graveolens," Journal of the Chinese Chemical Society, vol. 50, no. 1, pp. 171-178, 2003.

[6] S. E. El-Sherbeny, M. Y. Khalil, and M. S. Hussein, "Growth and productivity of Ruta graveolens under different foliar fertilizers application," Journal of Applied Sciences Research, vol. 3, no. 5, pp. 399-407, 2007.

[7] K. C. Preethi, G. Kuttan, and R. Kuttan, "Anti-tumour activity of Ruta graveolens extract," Asian Pacific Journal of Cancer Prevention, vol. 7, pp. 439-443, 2006.

[8] R. Freire, H. Borba, and C. Coelho, "Ruta graveolens L. toxicity in Vampirolepis nana infected mice," Indian Journal of Pharmacology, vol. 42, no. 6, pp. 345-350, 2010.

[9] I. G. Azizi, S. Masoud, and H. Karouei, "Effect of aquatic, methanolic and ethanoliclic extracts of Ruta graveolens on some mycotoxigenic fungi," American-Eurasian Journal of Agricultural and Environmental Sciences, vol. 12, pp. 729-732, 2012.

[10] T. G. De Freitas, P. M. Augusto, and T. Montanari, "Effect of Ruta graveolens L. on pregnant mice," Contraception, vol. 71, no. 1, pp. 74-77, 2005.

[11] K. H. Bohuslavizki, W. Hänsel, A. Kneip, E. Koppenhöfer, and A. Reimers, "Potassium channel blockers from Ruta--a new approach for the treatment of multiple sclerosis," General Physiology and Biophysics, vol. 11, no. 5, pp. 507-512, 1992.

[12] K. W. Chiu and A. Y. L. Fung, "The cardiovascular effects of green beans (Phaseolus aureus), common rue (Ruta graveolens), and kelp (Laminaria japonica) in rats," General Pharmacology: The Vascular System, vol. 29, no. 5, pp. 859862, 1997.

[13] J. Asgarpanah and E. Roohi, "Phytochemistry and pharmacological properties of Ruta graveolens L." Journal of Medicinal Plants Research, vol. 6, no. 23, pp. 3689-3993, 2012.

[14] R. C. Micael, S. M. Tahira, M. M. M. Fatima, and C. D. Jan, "Analgesic activity of Ruta graveolens L. (Rue) extracts," African Journal of Pharmacy and Pharmacology, vol. 9, no. 1, pp. 1-5, 2015.
[15] K. Yokoyama and D. R. Welchons, "The conjugation of amyloid beta protein on the gold colloidal nanoparticles' surfaces," Nanotechnology, vol. 18, 2007.

[16] V. K. Sharma, R. A. Yngard, and Y. Lin, "Silver nanoparticles: green synthesis and their antimicrobial activities," Advances in Colloid and Interface Science, vol. 145, no. 1-2, pp. 83-96, 2009.

[17] N. Hanžić, T. Jurkin, A. Maksimović, and M. Gotić, "The synthesis of gold nanoparticles by a citrate-radiolytical method," Radiation Physics and Chemistry, vol. 106, pp. 7782, 2015.

[18] H. Maleki, A. Simchi, M. Imani, and B. F. O. Costa, "Sizecontrolled synthesis of superparamagnetic iron oxide nanoparticles and their surface coating by gold for biomedical applications," Journal of Magnetism and Magnetic Materials, vol. 324, no. 23, pp. 3997-4005, 2012.

[19] K. Okitsu, A. Yue, S. Tanabe, H. Matsumoto, and Y. Yobiko, "Formation of colloidal gold nanoparticles in an ultrasonic field: control of rate of gold(III) reduction and size of formed gold particles," Langmuir, vol. 17, no. 25, pp. 7717-7720, 2001.

[20] S. Iravani, "Green synthesis of metal nanoparticles using plants," Green Chemistry, vol. 13, no. 10, p. 2638, 2011.

[21] V. Kumar and S. K. Yadav, "Plant-mediated synthesis of silver and gold nanoparticles and their applications," Journal of Chemical Technology \& Biotechnology, vol. 84, no. 2, pp. 151-157, 2009.

[22] P. Singh, Y. J. Kim, D. Zhang, and D. C. Yang, "Biological synthesis of nanoparticles from plants and microorganisms," Trends in Biotechnology, vol. 34, no. 7, pp. 588-599, 2016.

[23] M. Jeyaraj, G. Sathishkumar, G. Sivanandhan et al., "Biogenic silver nanoparticles for cancer treatment: an experimental report," Colloids Surfaces B Biointerfaces, vol. 106, pp. 86-92, 2013.

[24] D. R. Monteiro, S. Silva, M. Negri et al., "Silver nanoparticles: influence of stabilizing agent and diameter on antifungal activity against Candida albicans and Candida glabrata biofilms," Letters in Applied Microbiology, vol. 54, no. 5, pp. 383-391, 2012.

[25] K. K. Y. Wong and X. Liu, "Silver nanoparticles-the real "silver bullet" in clinical medicine?" Medchemcomm, vol. 1, no. 2, pp. 125-131, 2010.

[26] X. F. Zhang, Z. G. Liu, W. Shen, and S. Gurunathan, "Silver nanoparticles: synthesis, characterization, properties, applications, and therapeutic approaches," International Journal of Molecular Sciences, vol. 17, no. 9, p. 1534, 2016.

[27] S. Marimuthu, A. A. Rahuman, G. Rajakumar et al., "Evaluation of green synthesized silver nanoparticles against parasites," Evaluation of green synthesized silver nanoparticles against parasites, vol. 108, no. 6, pp. 1541-1549, 2011.

[28] P. V. Moorthi, C. Balasubramanian, and S. Mohan, "An improved insecticidal activity of silver nanoparticle synthesized by using Sargassum muticum," Applied Biochemistry and Biotechnology, vol. 175, no. 1, pp. 135-140, 2015.

[29] R. Gottesman, S. Shukla, N. Perkas, L. A. Solovyov, Y. Nitzan, and A. Gedanken, "Sonochemical coating of paper by microbiocidal silver nanoparticles," Langmuir, vol. 27, no. 2, pp. 720-726, 2011.

[30] I. Perelshtein, G. Applerot, N. Perkas, G. Guibert, S. Mikhailov, and A. Gedanken, "Sonochemical coating of silver nanoparticles on textile fabrics (nylon, polyester and cotton) and their antibacterial activity," Nanotechnology, vol. 19, no. 24, Article ID 245705, 2008.

[31] F. Martinez-Gutierrez, P. L. Olive, A. Banuelos et al., "Synthesis, characterization, and evaluation of antimicrobial and 
cytotoxic effect of silver and titanium nanoparticles," Nanomedicine: Nanotechnology, Biology and Medicine, vol. 6, no. 5, pp. 681-688, 2010.

[32] J. Sivakamavalli, O. Deepa, and B. Vaseeharan, "Discrete nanoparticles of Ruta Graveolens induces the bacterial and fungal biofilm inhibition," Cell Communication \& Adhesion, vol. 21, no. 4, pp. 229-238, 2014.

[33] M. Bordbar, "Biosynthesis of Ag/almond shell nanocomposite as a cost-effective and efficient catalyst for degradation of 4nitrophenol and organic dyes," RSC Advances, vol. 7, no. 1, pp. 180-189, 2017.

[34] T. T. N. Dung, V. N. Nam, T. T. Nhan et al., "Silver nanoparticles as potential antiviral agents against African swine fever virus," Materials Research Express, vol. 6, no. 2, Article ID 1250g9, 2019.

[35] L. C. Cefali, J. A. Ataide, S. Eberlin et al., "In vitro SPF and photostability assays of emulsion containing nanoparticles with vegetable extracts rich in flavonoids," AAPS PharmSciTech, vol. 20, no. 1, 2019.

[36] H. A. Ghramh, K. M. Al-Ghamdi, J. A. Mahyoub, and E. H. Ibrahim, "Chrysanthemum extract and extract prepared silver nanoparticles as biocides to control Aedes aegypti (L.), the vector of dengue fever," Journal of Asia-Pacific Entomology, vol. 21, no. 1, pp. 205-210, 2018.

[37] M. Kilany, "Isolation, screening and molecular identification of novel bacterial strain removing methylene blue from water solutions," Applied Water Science, vol. 7, no. 7, pp. 4091-4098, 2017.

[38] E. H. Ibrahim, R. Taha, H. A. Ghramh, and M. Kilany, "Development of rift valley fever (RVF) vaccine by genetic joining of the RVF-glycoprotein Gn with the strong adjuvant subunit B of cholera toxin (CTB) and expression in bacterial system," Saudi Journal of Biological Sciences, vol. 26, no. 7, pp. 1676-1681, 2018.

[39] M. Oves, M. S. Khan, A. Zaidi et al., "Antibacterial and cytotoxic efficacy of extracellular silver nanoparticles biofabricated from chromium reducing novel OS4 strain of Stenotrophomonas maltophilia," PLoS One, vol. 8, Article ID e59140, 2013.

[40] World Health Organization, Prevention and Control of Dengue Fever and Dengue Hemorrhagic Fever, Comphrehensive Guidelines, vol. 29, World Health Organization, Geneva, Switzerland, 2003.

[41] T. Mosmann, "Rapid colorimetric assay for cellular growth and survival: application to proliferation and cytotoxicity assays," Journal of Immunological Methods, vol. 65, no. 1-2, pp. 55-63, 1983.

[42] D. J. Finney, Probit Analises, vol. 14, Cambridge University Press, Cambridge, UK, 1972.

[43] W. S. Abbott, "A method of computing the effectiveness of an insecticide," Journal of Economic Entomology, vol. 18, no. 3, pp. 265-267, 1925.

[44] R. Ranganathan, S. Madanmohan, A. Kesavan et al., "Nanomedicine: towards development of patient-friendly drug-delivery systems for oncological applications," International Journal of Nanomedicine, vol. 7, pp. 1043-1060, 2012.

[45] S. A. Umoren, I. B. Obot, and Z. M. Gasem, "Green synthesis and characterization of silver nanoparticles using red apple (Malus domestica) fruit extract at room temperature," Journal of Materials and Environmental Science, vol. 5, 2014.

[46] I. Kuzovkina, I. Al'terman, and B. Schneider, "Specific accumulation and revised structures of acridone alkaloid glucosides in the tips of transformed roots of Ruta graveolens," Phytochemistry, vol. 65, no. 8, pp. 1095-1100, 2004.
[47] K. Fadlalla, A. Watson, T. Yehualaeshet, T. Turner, and T. Samuel, "Ruta graveolens extract induces DNA damage pathways and blocks Akt activation to inhibit cancer cell proliferation and survival," Anticancer Research, vol. 31, no. 1, pp. 233-241, 2011.

[48] M. Ratheesh, G. L. Shyni, G. Sindhu, and A. Helen, "Inhibitory effect of Ruta graveolens L. on oxidative damage, inflammation and aortic pathology in hypercholesteromic rats," Experimental and Toxicologic Pathology, vol. 63, no. 3, pp. 285-290, 2011.

[49] M. Ratheesh, G. Sindhu, and A. Helen, "Anti-inflammatory effect of quinoline alkaloid skimmianine isolated from Ruta graveolens L," Inflammation Research, vol. 62, no. 4, pp. 367-376, 2013.

[50] B. Hong, J. Kai, Y. Ren et al., "Highly sensitive rapid, reliable, and automatic cardiovascular disease diagnosis with nanoparticle fluorescence enhancer and mems," in Advances in Experimental Medicine and Biology, pp. 265-273, Springer, Berlin, Germany, 2008.

[51] L. Zhang, F. X. Gu, J. M. Chan, A. Z. Wang, R. S. Langer, and O. C. Farokhzad, "Nanoparticles in medicine: therapeutic applications and developments," Clinical Pharmacology \& Therapeutics, vol. 83, no. 5, pp. 761-769, 2008.

[52] M. Rai, A. Yadav, and A. Gade, "Silver nanoparticles as a new generation of antimicrobials," Biotechnology Advances, vol. 27, no. 1, pp. 76-83, 2009.

[53] C. F. Chau, S. H. Wu, and G. C. Yen, "The development of regulations for food nanotechnology," Trends in Food Science \& Technology, vol. 18, no. 5, pp. 269-280, 2007.

[54] H. Chang, M. Mi, W. Ling et al., "Structurally related anticancer activity of flavonoids: involvement of reactive oxygen species generation," Journal of Food Biochemistry, vol. 34, pp. 1-14, 2010.

[55] P. Vijayan, P. Vijayaraj, P. H. C. Setty et al., "The cytotoxic activity of the total alkaloids isolated from different parts of Solanum pseudocapsicum," Biological \& Pharmaceutical Bulletin, vol. 27, no. 4, pp. 528-530, 2004.

[56] M. Biradi and K. Hullatti, "Bioactivity guided isolation of cytotoxic terpenoids and steroids from Premna serratifolia," Pharmaceutical Biology, vol. 55, no. 1, pp. 1375-1379, 2017.

[57] R. J. Thoppil and A. Bishayee, "Terpenoids as potential chemopreventive and therapeutic agents in liver cancer," World Journal of Hepatology, vol. 3, no. 9, p. 228, 2011.

[58] A. Ivanova, B. Mikhova, H. Najdenski, I. Tsvetkova, and I. Kostova, "Antimicrobial and cytotoxic activity of Ruta graveolens," Fitoterapia, vol. 76, no. 3-4, pp. 344-347, 2005.

[59] T. Mocan, "Hemolysis as expression of nanoparticles-induced cytotoxicity in red blood cells," Biotechnology, Molecular Biology and Nanomedicine, vol. 1, no. 1, 2013.

[60] B. K. Gaiser, S. Hirn, A. Kermanizadeh et al., "Effects of silver nanoparticles on the liver and hepatocytes in vitro," Toxicological Sciences, vol. 131, no. 2, pp. 537-547, 2013.

[61] M. S. Heydrnejad, R. J. Samani, and S. Aghaeivanda, “Toxic effects of silver nanoparticles on liver and some hematological parameters in male and female mice (Mus musculus)," Biological Trace Element Research, vol. 165, no. 2, pp. 153-158, 2015.

[62] A. Ghosh, N. Chowdhury, and G. Chandra, "Plant extracts as potential mosquito larvicides," The Indian Journal of Medical Research, vol. 135, no. 5, 2012.

[63] A. Grzybowski, M. Tiboni, M. A. Silva, R. F. Chitolina, M. Passos, and J. D. Fontana, "Synergistic larvicidal effect and morphological alterations induced by ethanolic extracts of Annona muricata and Piper nigrum against the dengue fever 
vector Aedes aegypti," Pest Management Science, vol. 69, no. 5, pp. 589-601, 2013.

[64] P. M. Kumar, K. Murugan, K. Kovendan, J. Subramaniam, and D. Amaresan, "Mosquito larvicidal and pupicidal efficacy of Solanum xanthocarpum (Family: Solanaceae) leaf extract and bacterial insecticide, Bacillus thuringiensis, against Culex quinquefasciatus Say (Diptera: Culicidae)," Parasitology Research, vol. 110, no. 6, pp. 2541-2550, 2012.

[65] C. D. Patil, S. V. Patil, H. P. Borase, B. K. Salunke, and R. B. Salunkhe, "Larvicidal activity of silver nanoparticles synthesized using Plumeria rubra plant latex against Aedes aegypti and Anopheles stephensi," Parasitology Research, vol. 110, no. 5, pp. 1815-1822, 2012.

[66] P. Varamini, M. Soltani, and A. Ghaderi, "Cell cycle analysis and cytotoxic potential of Ruta graveolens against human tumor cell lines," Neoplasma, vol. 56, no. 6, pp. 490-493, 2009.

[67] H. P. Borase and C. D Patil, "Phyto-synthesized silver nanoparticles: a potent mosquito biolarvicidal agent," Journal of Nanomedicine \& Biotherapeutic Discovery, vol. 3, no. 1, 2013.

[68] P. Rajasekharreddy and P. U. Rani, "Biofabrication of Ag nanoparticles using Sterculia foetida L. seed extract and their toxic potential against mosquito vectors and HeLa cancer cells," Materials Science and Engineering: C, vol. 39, pp. 203-212, 2014. 